\title{
BENUTTING EN BEWARING VAN DIE LANDBOUPOTENSIAAL IN DIE REPUBLIEK VAN SUID-AFRIKA
}

\author{
D W IMMELMAN \\ Direkteur: Departement Landbou-tegniese Dienste \\ Privaatsak X116 \\ Pretoria \\ 0001
}

Abstract - The important role played by organized agriculture in modern society is emphasized and discussed against the current population explosion of mankind. Attention is focussed on the natural resources available to agriculture which include topography, climate, the soil, a diversity of vegetation types and water. The resources are subject to processes of erosion, bush encroachment, unfavourable ecological plant succession as well as other examples of misuse and mismanagement, all resulting in a lowering of the agricultural output and turnover. These detrimental processes cannot be tolerated and agricultural production therefore has to be in harmony with the environment and its natural resources in order to be economically viable. By implication this means an efficient classification of the agricultural resources incorporating the concept of nature conservation.

Voedsel en kleding is basiese behoeftes van die mens en hiervoor is hy hoofsaaklik van landbouproduksie afhanklik. Die voedselbronne van die see en die neweprodukte by die olienywerheid wat as kledingsbron dien, is van die weinige uitsonderings wat aangehaal kan word. Landbouproduksie en die aanwending van die landbouhulpbronne daarvoor is 'n absolute noodsaaklikheid vir ons voortbestaan en ontwikkeling.

Omdat die wêreld- sowel as ons eie-bevolking so intiem afhanklik is van landbouhulpbronne, is daar gevaartekens wat kommer baar oor die moontlikhede van landbouproduksie om in die toenemende behoeftes te voorsien. Die bevolking neem oor die hele aardbol teen 'n onrusbarende tempo toe en dit is veral so in die ontwikkelende lande. Die ontwikkelende lande huisves twee derdes van die wêreldbevolking maar produseer slegs ongeveer $40 \%$ van die totale voedselproduksie (Verbeek 1975). Die aanduidings is daar dat die situasie in die toekoms eerder sal vererger as verbeter. Daar sal dus toenemend op die voedselproduksievermoë van die ontwikkelde lande staat gemaak moet word. Die Republiek van Suid-Afrika (RSA) het 'n baie belangrike rol te vervul ten opsigte van voedselvoorsiening nie alleen aan sy eie bevolking nie maar 
ook ander lande wat nie voldoende voedsel produseer en selfs in die verre toekoms genoegsaam vir eie behoeftes sal kan lewer nie. Dit is belangrik om in gedagte te hou dat die bevolkingsaanwas in Afrika hoër is as in die res van die wêreld en verder dat die aanwas in die RSA op sy beurt weer hoër is as vir die res van Afrika (Anon 1975). Die jongste bevolkingsprojeksies vir die RSA van die Departement van Statistiek dui aan dat die totale bevolking 47 miljoen sal oorskry in die jaar 2000 en nagenoeg 72 miljoen sal beloop in die jaar 2020 (Dept. van Statistiek 1976).

Die voorafgaande is gestel met die uitsluitlike doel om lig te werp op die belangrikheid van die landbouhulpbronne naamlik, topografie, klimaat, grond, weiveld en waterbronne. Geen twyfel behoort te bestaan oor die hoë eise wat daar nog aan die bronne gestel gaan word nie en daarom is ' $n$ ontleding van ons landbouhulpbronne van pas.

Huidig het die RSA 103 miljoen ha vir landbouproduksie beskikbaar en oppervlakkig beskou mag dit voorkom asof ons oor 'n baie groot landboupotensiaal beskik en dit mag dus ook valse verwagtinge by ons skep. Die relatiewe groot oppervlakte bly ongelukkig nie staties nie omdat daar feitlik daagliks gebiede wat selfs oor betreklike hoë landboupotensiaal beskik vir ander gebruike afgestaan word, soos vir die ontwikkeling van stede en dorpe, nywerheidsgebiede, mynbou, spoorweë en paaie en vir ontspanning. Hierdie gebiede kry te meer betekenis as daar in aanmerking geneem word dat dit op groot skaal juis in die hoër potensiaal landbougebiede, soos die Hoëveld van Transvaal, plaasvind. Dit is logies dat grond vir ontwikkeling beskikbaar moet kom, maar ernstige besinning is nodig oor die wyse waarop grond deur ander sektore opgeneem word.

In die eerste plek wil ek graag kortliks stilstaan by klimaat. Die klimaat van die RSA word gekenmerk deur groot veranderlikhede ten opsigte van reënval en temperatuur. Ongeveer twee derdes van die oppervlakte ontvang 'n gemiddelde jaarlikse reënval van $500 \mathrm{~mm}$ of minder. Groot dele soos dele van die Karoo, Boesmanland, Namakwaland en die Kalahari kry minder as $250 \mathrm{~mm}$ per jaar. Afgesien van die relatiewe lae reënval wat oor die land as 'n geheel van toepassing is, mag die wisselvalligheid van die reënval ook nooit uit die oog verloor word nie. Dit het tot gevolg afwisselende nat en droë tye binne bepaalde groeiseisoene asook strawwe langdurige droogtes. Laasgenoemde is een van die kenmerkendste eienskappe waaronder landbouproduksie in die land beoefen word. Die uitwerking van langdurige droogtes sal in die toekoms toenemend belangriker word en daar moet deeglik mee rekening gehou word wanneer landboupotensiaal ge-evalueer word. Die groot temperatuurskommelinge van seisoen tot seisoen en tussen dag en nag, is ' $n$ belangrike faktor in landboupotensiaalbepaling omdat die lengte van die groeiseisoen asook die keuse van plante in 'n groot mate daardeur bepaal word.

Die RSA is nie goed voorsien van hoë potensiaal landbougronde nie. Van die totale oppervlakte beskikbaar vir landbou is daar ongeveer $15 \%$ 
wat geskik is vir bewerking. In 1960 was daar ongeveer 1 ha bewerkbare grond per kop van die bevolking beskikbaar. Daarvan was ongeveer driekwart reeds onder bewerking met omtrent 'n kwart nog in reserwe. In dieselfde stadium het die wêreld nog ongeveer 1,5 ha per kop van sy bevolking in reserwe gehad (Du Plessis 1968). Wat werklik as goeie grond in die RSA bestempel kan word, word deur ongeveer 4 miljoen ha of $4 \%$ van die totale oppervlakte beslaan. Dié oppervlakte is vir nagenoeg $40 \%$ van die totale waarde van landbouproduksie verantwoordelik (Tomlinson 1968).

By verre die grootste gedeelte $(85 \%)$ van ons landsoppervlakte word deur natuurlike weiveld beslaan. Vanuit 'n botaniese oogpunt beskik ons oor 'n unieke rykdom van plante. Ongeveer 18000 inheemse plante kom voor, in vergelyking met die Verenigde State van Amerika (VSA) se 15000 en Rusland se 20000 terwyl laasgenoemde 'n sesde van die wêreld se landoppervlakte beslaan (Tidmarsh 1968). As ons egter vanuit die landboukundige oogpunt na hierdie groot bate kyk, dan is dit weer eens duidelik dat die weivelde van ons land nie deurgaans oor ' $n$ hoë potensiaal beskik nie. Ongeveer $25 \%$ daarvan beskik oor 'n dravermoë van naasteby 18 ha per grootvee-eenheid, terwyl 'n verdere bykans $30 \%$ 'n drakrag het wat wissel van 8 ha tot 15 ha per grootvee-eenheid. Dit dui daarop dat meer as die helfte van die weiveld oor 'n relatiewe lae dravermoë beskik (Dept. van Landbou-tegniese Dienste 1972).

Watervoorrade is baie beperk in die Republiek van Suid-Afrika. Berekenings dui daarop dat bestaande voorrade en verdere uitbreiding van fasiliteite om tans onbenutte oppervlakte waters in te span, die RSA tot om en by die begin van die nuwe eeu van voldoende water sal kan voorsien. Tans word ongeveer $80 \%$ van die beskikbare watervoorrade deur die landbousektor benut. Die verwagting is dat die landbousektor nie weer op aansienlike toenames in waterverbruik sal kan staatmaak nie. Alhoewel die opgaar van oppervlakte-waters met nog bykans 'n $100 \%$ sal toeneem, sal die totale verbruik deur die landbousektor teen dieselfde tyd op $40 \%$ van die totale verbruik neerkom. Doeltreffende aanwending van die beskikbare voorrade sal gevolglik die wagwoord moet wees in die landbousektor.

Die topografie wissel van uitgestrekte vlaktes tot golwende en uiters bergagtige landskappe. Die vlaktes gaan hoofsaaklik gepaard met laer reënvaltoestande terwyl die golwende en bergagtige landskappe meerendeel met die hoër reënvalgebiede geassosieer kan word. Dit beteken dus dat die faktore klimaat en topografie met die oog op bepaling van landboupotensiaal eerder kompeterend in stede van komplimenterend op mekaar inwerk.

Die landboupotensiaal van 'n bepaalde stuk grond word nie deur 'n enkel faktor soos grond, weiveld of klimaat afsonderlik bepaal nie, maar wel deur die interaksie van die verskillende omgewingsfaktore. Enige landboustreek of plaas beskik oor ' $n$ inherente landboupotensiaal. Dit dui op die landbouproduksiemoontlikhede wat voortvloei uit die gesa- 
mentlike en afsonderlike invloede van die natuurlike omgewingsfaktore waarvan topografie, klimaat, grond, plantegroei en watervoorrade die belangrikste is. Eenvoudig gestel, bepaal hierdie faktore hoe suksesvol 'n bepaalde gewas op 'n bepaalde plek verbou kan word. Die eerste vereiste vir die suksesvolle optimale verbouing van 'n gewas is dat dit in harmonie moet wees met die landbouproduksiemoontlikhede wat die natuurlike omgewingsfaktore bied. Om binne die perke wat die omgewingsfaktore dikteer te bly wanneer 'n enkel gewas geproduseer word, is betreklik eenvoudig. Die proses word egter oneindig meer ingewikkeld wanneer ' $n$ volledige boerderystelsel in harmonie met die landboupotensiaal uitgevoer moet word (Tomlinson 1968).

$\mathrm{Na}$ aanleiding van die bogenoemde uiteensetting oor landbouhulpbronne, behoort dit duidelik te wees waarom die bronne so kwesbaar is vir agteruitgang. Dit is bekend dat ons gronde oor uitgestrekte gebiede besonder kwesaar is vir erosie en dat die weiveld baie onderhewig aan agteruitgang is. Dit is ongelukkig die geval dat die landbouhulpbronne in 'n mindere tot 'n ernstiger mate, in verskillende dele van die land na gelang van die aard van die kwesbaarheid, geskaad is. Daar bestaan verskeie redes waarom die hoë kwesbaarheid van die landboupotensiaal nie na waarde geskat is nie. Dit sal ongelukkig nie moontlik wees om by die geleentheid volledig daarop in te gaan nie. Faktore soos die trek na die binneland, die geredelike beskikbaarheid van nuwe weivelde, en die gebrek aan tegniese kennis en fasiliteite is almal oorsake wat tot die agteruitgang van die bodem gelei het.

Dit is reeds aangetoon dat ongeveer $85 \%$ van die beskikbare landbougrond deur natuurlike weiveld beslaan word. Dit is verder algemeen bekend dat weivelde oor die algemeen aansienlike veranderinge ondergaan het ten opsigte van plantsamestelling sowel as die digtheid van die bedekking. Dit is onteenseglik so dat die gebruik van die natuurlike veld deur die dier 'n invloed op die plantegroei uitoefen en dat dit gelei het tot uitgebreide agteruitgang. Dit sou egter nie korrek wees om alle verandering of agteruitgang wat in die plantegroei in dele van ons land plaasgevind het onder alle omstandighede slegs aan die landbou toe te dig nie. Die samestelling van die plantegroei op 'n gegewe tydstip verteenwoordig slegs 'n snit uit 'n vloeibare toestand wat steeds aan die beweeg is. Dit word geillustreer in Tabel 1 waarin getoon word hoe die plantegroei in die omgewing van Aliwal-Noord oor' $n$ tydperk van 3000 jaar gewissel het sonder dat landbou 'n noemenswaardige rol gespeel het. Die plantegroeitipes wat daar bestaan het is afgelei van versteende stuifmeel gevind in 'n moeras tot op 'n diepte van nagenoeg 10 meter.

Enige indrukke of opvattings ten opsigte van stabiliteit in die plantegroei, vooruitgang of agteruitgang en wat bewaar moet word, moet beslis met die nodige voorbehoude geformuleer word. Die invloed van klimaat op die samestelling van plantegroeitipes en veranderings daaraan is oorheersend, maar die spoed waarteen veranderings plaasvind kan onder huidige omstandighede vertraag of versnel word deur die 
Wisseling van die plantegroei in Aliwal-Noord omgewing oor 'n periode van ongeveer 3000 jaar (volgens Coetzee 1968)

\begin{tabular}{|c|c|c|c|}
\hline $\begin{array}{l}\text { Grond- } \\
\text { diepte } \\
\text { (meter) }\end{array}$ & $\begin{array}{l}\text { Ouderdom in jare } \\
\text { volgens } \mathrm{C}^{14} \\
\text { bepaling }\end{array}$ & $\begin{array}{c}\text { Plante- } \\
\text { groei } \\
\text { teenwoordig }\end{array}$ & $\begin{array}{l}\text { Klimaat } \\
\text { (afgelei) }\end{array}$ \\
\hline 5,4 & 9500 & Karoo en Droë grasveld & Warm en droog \\
\hline 6,1 & 10000 & Grasveld & Koeler en meer vogtig \\
\hline 7,5 & 11400 & Karoo & Baie warm en droog \\
\hline 8,2 & 12000 & Suiwer grasveld & Koel en vogtig \\
\hline 8,7 & 12400 & Karoo & Warm en droog \\
\hline 9,6 & 12600 & Grasveld en Macchia & Koud en vogtig \\
\hline
\end{tabular}

bestuurspraktyk wat beoefen word. Die indringing van Karootipe plantegroei in die aangrensende grasvelde in noordelike en oostelike rigtings, word bevestig deur plantopnames (Acocks 1975) en word verder op 'n baie treffende wyse deur satelietfotos van die ERTSprogram geïllustreer. 'n Ondersoek in die opvanggebied van die Hendrik Verwoerddam, wat ten tye toe landbouontwikkeling begin het deur suiwer grasveld beslaan was, toon dat slegs ongeveer $22 \%$ van die oppervlakte nog oor 'n betekenisvolle grasbedekking beskik, terwyl die res deur bossieveld en bossie met gras gemeng beslaan word (Immelman 1967).

Bosveldgebiede beslaan in die RSA alleen nagenoeg 21 miljoen ha met ongeveer 19 miljoen ha in Suidwes-Afrika. Oor bykans die helfte van hierdie oppervlaktes het die natuurlike bos (inheemse soorte) sodanig verdig dat dit grasproduksie en gevolglik diereproduksie onderdruk. Die belangrikste indringerspesies is Acacia mellifera var detines (Swarthaak), Acacia karoo (Soetdoring), A. nilotica (Lekker-reuk-peul), A. tortilis (Haak-en-steek) en Dichrostachys cinerea (Sekelbos). Die graad van bosverdigting varieer aansienlik en stande van tot 3000 bome per ha is reeds bepaal. Proefnemings in die Oos-Kaap dui daarop dat stande van 800 bome per ha die grasproduksie sal halveer ongeag die reënval. Bosverdigting het in sommige dele reeds sodanige afmetings aangeneem dat dit nie met biologiese maatreëls alleen bekamp sal kan word nie en sal chemiese en meganiese beheermaatreëls deel vorm van toekomstige boerderypraktyke.

In die meeste van die bergopvanggebiede van Suidwes-Kaapland, die Karoo en Oos-Kaapland is groot dele sodanig ingedring deur fynbosgemeenskappe dat dit landboukundig onproduktief is en ook grootskaalse gronderosiegevare inhou. Soos in die geval van die bosveldgebiede moet die oordeelkundige gebruik van vuur en chemiese middels oorweeg word 
om die bedekking na grasveld te verander wat beide die grond sal stabiliseer en landboukundig produktief sal wees. Die belangrikste indringerspesies is: Elytropappus rhinocerostis (Rhenosterbos), Euryops spp. (Harpuis), Cliffortia linearitolia en Erica brownleae.

In sommige van die hoë reënvalgebiede is die natuurlike plantontwikkeling in 'n stadium waarin grasse soos Cymbopogon spp. en Festuca spp. domineer. Dit word ekologies beskou as 'n hoër stap as bv. Themeda-veld maar besit nie dieselfde weidingswaarde nie. Die indringing van onsmaaklike grassoorte is een van die moeilikste probleme waarmee landboukundiges te doene kry. Dit moet hoofsaaklik aan selektiewe beweiding van die smaaklike grassoorte toegeskryf word. Hierdie veranderinge is gewoonlik nie ooglopend nie en verteenwoordig nie noodwendig grootskaalse veranderings in die plantesuksessie nie. Daar word bereken dat in sekere gebiede reeds meer as $50 \%$ van die oppervlakte weiveld deur onsmaaklike grassoorte beslaan word wat 'n ernstige neerdrukkende uitwerking op veeprestasie uitoefen. Die belangrikste ongewenste soorte is: Aristida spp., Eragrostis spp., Elyonurus argenteus, Rendlia altera en Cymbopogon plurinodes.

Die nadelige uitwerking wat uitheemse plante en gifplante op die weidingspotensiaal uitoefen, kan ook nie uit die oog verloor word nie. Wat uitheemse plante betref word veral gedink aan Opuntia aurantiaca (Litjieskaktus) wat reeds ongeveer 1800000 ha in die RSA besmet het, Acacia cyanophylla (Port Jackson), Hakea gibbosa, Acacia dealbata (Silwer Wattel), Lantana comara, Prosopis juliflora, Stipa trichotoma (Nasellapolgras). Gifplante is in die meeste gevalle inheems en kom in feitlik alle veldsoorte en klimaatsgebiede voor. Van die belangrikste soorte is: Gousiekte (Paghystigma sp.), Gifblaar (Dichapetalum sp.), Vermeerbos (Geigeria sp.), Tulp (Homeria sp. en Moraea sp.), Stywesiekte (Crotolaria sp.) en Senecio spesies. Daar is egter aanduidings dat die nadelige invloed van gifplante in 'n groot mate bekamp kan word deur die handhawing van realistiese veebeladings en goeie bestuurspraktyke.

Benewens die feit dat die RSA oor 'n relatief geringe persentasie bewerkbare grond beskik, is die gronde wat wel bewerkbaar is nie deurgaans van 'n hoë standaard nie en daarom is die gronde ook baie onderhewig aan erosie deur wind en water. Daar is nie gegewens beskikbaar om die verliese wat die akkerbougronde reeds as gevolg van erosie gely het te weerspieël nie. Daar kan egter met veiligheid beweer word dat gevoelige verliese reeds voorgekom het en dit sluit selfs nie die hoë potensiaal gebiede uit nie. Bewerkte gronde met oënskynlik lae hellings is ook aan erosie onderhewig en verloor 'n groot tonnemaat grond tydens stortreëns. Net soos in die geval van watererosie is daar ook geen bepaalde gegewens om die omvang van winderosie te weerspieël nie. Daar is wel gegewens vir die opvanggebied van die Bo-Oranje beskikbaar wat as aanduiding kan dien van die omvang en gevare wat erosie op landerye inhou (Immelman 1967). Hier kom op $76 \%$ van die plase bladerosie op landerye voor en op $50 \%$ van die plase is slootjies op 
die lande aanwesig. Ongeveer $7 \%$ van die oppervlakte onder landerye toon tekens van winderosie. Waaisand aan die kus en die onmiddellike aangrensende binneland, hou ook besondere probleme in. Vanaf die mond van die Oranjerivier tot by Plettenbergbaai is daar langs die Wesen Suidkus ongeveer 55000 ha wat aan waaisand onderhewig is.

In dele van die land neem gevorderde gronderosie in die vorm van totale ontbloting van die ondergrond en dongas skrikwekkend afmetings aan. Daar is ook nie gegewens beskikbaar om die toestande landswyd te kwantifiseer nie. Die omvang wat erosie in die Vlekpoortgebied (Hofmeyr Distrik) aanneem is algemeen bekend. Dieselfde tipe erosie neem groot afmetings aan in die Karoo, Suid- en Oos-Vrystaat en NoordoosKaap. 'n Ondersoek in die opvanggebied van die Bo-Oranje toon dat $10 \%$ van die totale oppervlakte van die weiveld aan dié tipe erosie onderhewig is (Immelman 1967). Dit is dan ook vanaf die oppervlaktes waar die grootste grondverliese per eenheid oppervlakte plaasvind.

Die oppervlakte waterbronne van die land het oor die jare aansienlike verandering en agteruitgang geopenbaar. Op talle plase is die ou name wat 'n permanente stroom of sterk fonteine impliseer nie meer van toepassing nie. Plaaswonings wat op grond van 'n destydse standhoudende waterbron aangelê is, staan vandag verlate met geen teken van enige waterbron in die nabyheid nie. Die kwaliteit van die water wat in die meeste van ons riviere vloei word ongelukkig ook erg benadeel as gevolg van die sedementlading wat dit dra. Die nadelige uitwerking van groot sedimentladings op die waterkapasiteit van opgaardamme is bekend.

Soos en namate die veebedryf en droëlandgewasproduksie die landsoppervlakte vollediger geëksploiteer het, het besproeiing na 'n aanvanklike stadige begin steeds groter momentum gekry gedurende die jongste jare. Net soos daar in die gevalle van vee- en droëlandgewasproduksie foute begaan is met die benutting van die betrokke landbouhulpbronne, is daar ook foute gemaak tydens die ontwikkelingsjare van die besproeiingsbedryf. Die oppervlakte onder besproeiing het gegroei vanaf 100 ha in die tweede helfte van die $17 \mathrm{de}$ eeu tot ongeveer 1000000 ha wat huidig onder besproeiing is of geoormerk is daarvoor. Weens gebrekkige kennis van die hoogs ingewikkelde grondwater aksies en interaksies wat met besproeiing gepaard gaan, sowel as ontoereikende kapitaalinvestering in beskermingsmaatreëls, het versuiping en mineralisasie, of soos dit algemeen bekend staan - verbrakking, geleidelik groot afmetings aangeneem. Dit word beraam dat sowat 100000 ha besproeiingsgrond in die RSA aan verskillende grade van versuiping en verbrakking onderhewig is. Hierdie gronde beskik juis oor die grootste landboupotensiaal. Dit is van die grootste belang dat verdere verbrakking aan bande gelê word en dat waar dit reeds plaasgevind het, die verskil in produktiwiteit bewerkstellig moet word.

Die vraag kan seker tereg gevra word of landbouontwikkeling nie ook die oorsaak is vir ' $n$ wanbalans in die makro- en mikrobiologiese lewe 
nie, en verder of dit nie ook gesien kan word as 'n verlies aan 'n bate wat nie net in die algemeen geldig is nie maar ook op die landbou van toepassing is. Dit is die vrae wat die natuurliefhebber en -bewaarder homself mag afvra. As gevolg van die RSA se warm klimaat en ryk insekfauna is ons landbougewasse onderhewig aan 'n aansienlike plaagdruk. Alhoewel die landbou dikwels daarvan beskuldig word dat hy sy plaagprobleme uitsluitlik deur middel van chemiese plaagbeheermaatreëls probeer oplos - met verreikende nadelige gevolge op sy omgewing is daar in die verlede en word daar steeds heelwat aandag deur die Departement van Landbou-tegniese Dienste (LTD) aan alternatiewe bestrydingsmaatreëls bestee. Verbouingspraktyke kan daartoe bydra om plae in bedwang te hou. Die teling van plantkultivars wat siekte- en insektebestandheid toon kan aansienlik help om die aanwending van plaagbeheermiddels te beperk. Die benadering verg egter jarelange navorsing om vir bestandheid en gepaardgaande hoë produktiwiteit te selekteer. Verder vereis ons landbou geskikte kultivars vir verskillende klimatologiese gebiede. Alhoewel die benadering tydrowend is bestee die Departement baie aandag in die rigting en gelukkig ook met goeie gevolge soos blyk uit die ontwikkeling van bladspringer-bestande katoenkultivars en siektebestande aartappelkultivars wat onlangs deur die Departement vrygestel is. Dan is daar die biologiese beheer wat die onderdrukking van plaagspesies deur middel van ander lewendige organismes waarmee reeds verskeie uitstaande suksesse behaal is. Daar moet egter altyd onthou word dat totale beheer van sekere plae nodig is om die produsent in staat te stel om aan markstandaarde te voldoen en om sodoende die waarde van die oes te verseker. In sodanige gevalle is die aanwending van chemiese bestrydingsmiddels gewoonlik onontbeerlik. Ten spyte van die aanwending van chemiese bestrydingsmiddels kan ons in die RSA trots wees op die betreklike lae peil van reste in die verskeie komponente van die omgewing - veral die mens - wat tot dusver gemonitor is. Die vernaamste redes hiervoor is dat hoë voorkomende grondtoedienings van standhoudende middels nie in Suid-Afrika aanbeveel word nie en die gebruik dus relatief beperk is en omdat dié middels indien wel aangewend onder ons klimaatstoestande baie vinniger afbreek as in lande met veral 'n meer gematigde klimaat.

Met die voorafgaande is gepoog om die belangrikheid en noodsaaklikheid van landbouontwikkeling in die RSA te beklemtoon teen die agtergrond van 'n snel groeiende bevolking, betreklike skaars landbouhulpbronne en dié mate van agteruitgang wat die landbouhulpbronne reeds ondergaan het.

Indien die relatiewe skaarste aan landbouhulpbronne en die mate van aftakeling wat dit reeds ondergaan het saam gesien word met die feit dat daar in die toekoms steeds groter druk daarop uitgeoefen sal moet word, dan wek dit werklik kommer. Die vraag na landbouprodukte gaan teen 'n versnelde tempo toeneem en dit sal beteken dat die landbouhulpbronne meer intensief benut sal moet word. Die groter vraag na 
landbouprodukte is onder andere 'n faktor wat die prys vir landbougrond sal laat styg. Daar het reeds oor die afgelope paar jaar aansienlike prysstygings vir landbougrond plaasgevind (Tabel 2).

\section{TABEL 2}

Indekse van grondpryse vanaf 1970/71 tot 1975/76 (volgens die Departement van Landbou-ekonomie en Bemarking 1976)'

\begin{tabular}{c|c|c|c|c|c|c}
\hline Jaar & $\begin{array}{c}\text { Somer- } \\
\text { saai- } \\
\text { streek } \\
\text { (a) }\end{array}$ & $\begin{array}{c}\text { Winter- } \\
\text { saai- } \\
\text { streek } \\
\text { (b) }\end{array}$ & $\begin{array}{c}\text { Bees- } \\
\text { wei- } \\
\text { streek } \\
\text { (c) }\end{array}$ & $\begin{array}{c}\text { Skaap- } \\
\text { wei- } \\
\text { streek } \\
\text { (d) }\end{array}$ & Natal & $\begin{array}{c}\text { Gekom- } \\
\text { bineerd }\end{array}$ \\
\hline $1970 / 71$ & 100 & 100 & 100 & 100 & 100 & 100 \\
$1971 / 72$ & 112 & 126 & 107 & 111 & 116 & 112 \\
$1972 / 73$ & 116 & 124 & 136 & 110 & 109 & 120 \\
$1973 / 74$ & 125 & 135 & 161 & 108 & 137 & 133 \\
$1974 / 75$ & 148 & 157 & 188 & 132 & 167 & 158 \\
$1975 / 76$ & 186 & 201 & 268 & 154 & 181 & 203 \\
\hline
\end{tabular}

1. Saamgestel op basis van transporte van plattelandse onroerende eiendomme, gepubliseer deur die Departement van Statistiek. April 1970 tot Maart 1971 is gelyk gestel aan 100.

(a) Balfour, Bethal, Delmas, Frankfurt, Standerton, Heilbron, Koppies, Bethlehem, Clocolan, Ficksburg, Fouriesburg, Ladybrand, Coligny, Delareyville, Klerksdorp, Lichtenburg, Schweizer-Reneke, Ventersdorp, Wolmaransstad, Bothaville, Kroonstad, Odendaalsrus, Viljoenskroon, Vredefort, Wesselsbron.

(b) Malmesbury, Piketberg, Bredasdorp, Caledon, Swellendam.

(c) Kuruman, Mafeking, Vryburg, Potgietersrus, Soutpansberg, Thabazimbi, Waterberg.

(d) Calvinia, Carnarvon, Frazerburg, Kenhardt, Sutherland, Aberdeen, Beaufort-Wes, Britstown, Colesberg, Graaff-Reinet, Hanover, Victoria-Wes.

(e) Kliprivier, Pietermaritzburg, Umvoti, Utrecht, Vryheid, Weenen.

Tabel 2 dui aan dat die gekombineerde indeks vir grondpryse oor die afgelope vyf jaar ongeveer verdubbel het, Die styging in grondpryse baar kommer omdat dit noodwendig moet lei tot die intensifisering van die produksieproses en dat dit sal beteken dat die landbouhulpbronne meer intensief aangewend sal word en dus die moontlikheid van verdere agteruitgang inhou. Wanneer daar intensifiseer word beteken dit dat groter energie-insette in die produksieproses gemaak word. In die VSA is ondervind dat brandstofverbruik in die landbouproduksieproses vanaf 1963 tot 1973 van 'n daaglikse verbruik van 23 miljoen vate tot 36 miljoen gestyg het en dat die verwagte verbruik in 1985 op 53 tot 67 miljoen vate bereken word (Organization for Economic Co-operation and Development 1975). Die gemiddelde kilowatt trekkerenergie per trekker in die RSA sedert 1960 is ook besonder insiggewend in die 
verband aangesien dit vanaf 0,4 kilowatt per ha gestyg het tot 1,0 per ha in 1970. Dit kom neer op meer as 'n verdubbeling (Dept. LTD 1976).

Die relatiewe verhouding tussen koste van vaste verbeterings, werktuie en arbeid in die voerdery gee ook 'n baie goeie aanduiding wat onder Suid-Afrikaanse toestande besig is om te gebeur (Tabel 3).

TABEL 3

Die relatiewe verskuiwing tussen vaste verbeterings-, werktuig- en arbeidskoste in die Transvaalse Hoeveld, 1947/48, 1954/55, 1969/70 en 1974/75 (volgens Dept. van Landbou-ekonomie en Bemarking 1976)

\begin{tabular}{c|c|c|c}
\hline \multirow{2}{*}{ Jaar } & \multicolumn{3}{|c}{ Relatiewe verhouding tussen kostes van: } \\
\cline { 2 - 4 } & Werktuie & $\begin{array}{c}\text { Arbeid } \\
\text { Persentasie }\end{array}$ & $\begin{array}{c}\text { Vaste } \\
\text { Verbeterings }\end{array}$ \\
\cline { 2 - 4 } $1947 / 48$ & 26,6 & 68,3 & 5,1 \\
$1954 / 55$ & 55,0 & 40,7 & 4,3 \\
$1969 / 70$ & 59,6 & 35,0 & 5,3 \\
$1974 / 75$ & 66,9 & 28,9 & 4,2 \\
\hline
\end{tabular}

Tabel 3 dui op die groot insette wat daar in die landbou in meganisasie gemaak word, wat 'n verdere aanduiding is van die intensifikasie wat plaasvind - met weer eens die gevaar vir die aftakeling van die landbouhulpbronne indien daar nie daadwerklik teen gewaak word nie. In die opsig is die volgende aanhaling van die AdjunkSekretaris van Landbou in die VSA insiggewend: "If American farmers had not so enthusiastically accepted the conservation movement in the past we would not have been able to meet today's expanding demand so effectively. That lesson cautious us not to turn our backs on good conservation practices as we go all-out to meet the opportunities of tomorrow's market" (Campbell 1973).

Indien die groter energie insette nie met die beskerming van die landbouhulpbronne teen erosie en agteruitgang sou rekening hou nie, kan grootskaalse probleme in die RSA verwag word. Dit kan net vertrou word dat die stygende insette van energie ook deels in die bewaringsrigting gekanaliseer word.

Dit is vanweë die belangrikheid van landbouontwikkeling en te meer dat dit op 'n gesonde grondslag moet geskied sonder dat die landbouhulpbronne skade ly dat die Departement LTD in die lig van omstandighede aan die begin van die dekade sy hooftaak duidelik geformuleer het naamlik optimale bodembenutting en dit behels dat: 
Landbouproduksie moet in harmonie met die natuurlike omgewingsfaktore geskied wat impliseer dat die boerderybedryfstakke in ' $n$ bepaalde benuttingstelsel in harmonie moet wees met die landbouproduksiemoontlikhede. Dit beteken dus bv. dat daar onder drooglandtoestande nie geploeg behoort te word waar die omgewingsfaktore hul slegs vir ekstensiewe veeproduksie leen nie.

Landbouproduksie mag nie ten koste van die landbouhulpbronne geskied nie. Die feit dat ' $n$ bepaalde bedryfstak in harmonie met die omgewingsfaktore is, is nie 'n waarborg dat die inherente produksievermoë van 'n hulpbron nie ooreis en sodoende beskadig of vernietig kan word nie. 'n Aangepaste veevertakking moet steeds rekening hou met die dravermoë van die natuurlike weiding.

Landbouproduksie moet op 'n ekonomiese grondslag geskied. Hoewel die omgewingsfaktore en korrekte gebruik van hulpbronne dus ' $n$ bepaalde grondgebruikspatroon dikteer, moet in ag geneem word dat die toepassing van korrekte boerderytegnieke binne onderskeie boerderybedryfstakke, en die optimum kombinasie van boerderybedryfstakke met die oog op maksimum wins, nou geintegreer is in die totale opset van goeie boerdery. Optimale benuttingstelsels moet onder andere voorsiening maak dat die boer op sy plaas 'n menswaardige bestaan kan voer, so nie is dit onuitvoerbaar en waardeloos.

Benewens die duidelike formulering van die hooftaak van die Departement was dit ook noodsaaklik dat daar oor die uitvoering van sodanige taak besin word. Ten einde 'n sinvolle nastrewing van die ideaal van optimale bodembenutting te verkry, val die kalklig op verskeie fasette waaraan gelyktydig asook in opvolging op mekaar aandag gegee moet word. Die verskillende fasette is: klassifikasie van die landbouhulpbronne, daarstelling van opbrengsnorme en produksietegnieke aan die hand van die klassifikasie van die landbouhulpbronne, formulering van riglyne vir aangepaste boerderystelsels vir redelike homogene boerderygebiede, verskaffing van voorligtingsdienste, lewering van bepaalde dienste en administrasie van gepaardgaande wette, volgehoue navorsingsprogram en die koördinering van die beskikbare landboukundige mannekrag hetsy staat, semi-staat of privaat.

Die Departement LTD is besig met 'n klassifikasiesisteem waarvolgens die landbouhulpbronne in drie klasse ingedeel word nl. ekotope, landtipes, en landsisteme (MacVicar, Scotney, Skinner, Niehaus en Loubser (1974). 'n Ekotoop is 'n landklas waar in terme van makroklimaat (insluitende aspek waar nodig) grond- en grondoppervlakte eienskappe (helling) op so 'n wyse omskryf word dat daar ten opsigte van boerderypraktyke, die opbrengsklas of boerderybestuur betekenisvolle verskille is tussen een ekotoop en enige ander. 'n Landtipe is 'n landklas waarin die makroklimaat, landvorm en die grondpatroon elkeen 'n groot mate van gelykvormigheid openbaar. Hierdie mate van gelykvormigheid 
is sodanig dat daar weinig voordeel in verdere onderverdeling in meer gelykvormige landskappe sal wees. 'n Landtipe bestaan uit 'n aantal ekotope waarvan die geaardheid en oppervlakte bekend is en die som van die oppervlaktes van die ekotope gelyk is aan die oppervlakte van die landtipe. 'n Landsisteem is 'n landklas waarin die makroklimaat, landvorm en grondpatroon, of een of twee van hierdie 'n geringer mate van gelykvormigheid openbaar as wat die geval is by landtipes. Die verskille in landbouhulpbronne wat landsisteme onderskei sal noodwendig belangrike verskille in potensiële landgebruik meebring. ' $n$ Landsisteem word deur 'n aantal landtipes beslaan.

Die klassifikasie van die landbouhulpbronne sou sinneloos wees indien dit nie in verband gebring word met die bepaling van opbrengsnorme, produksietegnieke en die formulering van riglyne vir aangepaste boerderystelsels vir redelike homogene boerderygebiede nie. Die neerlegging van norme en tegnieke sal op 'n ekotoopbasis geskied, terwyl breëre riglyne op veral landtipes en ook landsisteme van toepassing gemaak sal word. Die opbrengsnorme en produksietegnieke sal op die basis van die beste boer potensiaal bepaal word. Verder sal die norme en produksietegnieke rekening hou met die vereistes vir die beskerming van die landbouhulpbronne.

Die klassifikasie van die landbouhulpbronne tesame met die neerlegging van norme, tegnieke en riglyne vorm 'n uitstekende basis vir landbouvoorligtingsprogramme. Dit word vertrou dat die ordening van inligting op so 'n sistematiese wyse en wat dan met doeltreffende voorligtingsprogramme opgevolg kan word, grootliks sal bydra om die gaping wat daar tussen beskikbare navorsingsinligting en die toepassing daarvan in die praktyk bestaan, aansienlik te vernou. Die feit dat die aanvaarding van nuwe praktyke in die boeregemeenskap volgens 'n normale verspreidingskurwe geskied dui daarop dat 'n landvoorligtingsaksie in teenstelling met slegs die ad hoc verspreiding van inligting noodsaaklik is.

Die administrasie van bepaalde wette en die lewering van meegaande dienste is ' $\mathrm{n}$ onontbeerlike faktor in die landbouontwikkelingsproses. Meer bepaald wat die bewaring van die landbouhulpbronne betref administreer die Departement LTD twee belangrike wette nl. die Grondbewaringswet en die Wet op die Onderverdeling van Landbougrond. Uitgebreide dienste en finansiële ondersteuning word onder die Grondbewaringswet ter beskerming van die landbouhulpbronne verleen. Na verwagting sal daar ongeveer R48 miljoen onder die verminderingskema in die droër skaapweistreke van die land ter behoud van die natuurlike weiveld spandeer word. Daar word ook jaarliks in die omgewing van R2 miljoen aan subsidies vir die oprigting van bewaringsfasiliteite aan boere in die RSA uitbetaal.

Landbounavorsing moet hoofsaaklik aan die hand van die neergelegde opbrengsnorme en produksietegnieke beplan en uitgevoer word. Die sluimerende potensiaal van die landbouhulpbronne moet voortdu- 
rend deur landbounavorsing ontgin word om sodoende nuwe verhoogde mikpunte ten opsigte van opbrengsnorme daar te stel tesame met die ontwerp van tegnieke waarvolgens dit bereik kan word. Navorsing is daarop toegesê om voorrang te verleen aan prioriteitsaangeleenthede. Prioriteitsbepaling sal ook vergemaklik word as die navorsing op die basis van bestaande norme en tegnieke beplan sou word. Die Departement LTD beskik oor ' $n$ uitgebreide en doeltreffende navorsingsdiens wat sonder enige twyfel in staat is om te voldoen aan die eise wat daaraan gestel word.

Die Departement LTD is nie die alleenheerser op die gebied van landbounavorsing en alleenverskaffer op die gebied van inligting nie. Dit is noodsaaklik dat die landboukundige kragte doeltreffend koördineer word veral in die lig van ons skaarste aan opgeleide mannekrag. Gelukkig is daar ook op die terrein bemoedigende tekens. Die huidige poging deur die Departement, Suid-Afrikaanse Landbou-Unie en bepaalde privaat niewinsgewende Verenigings om kragte in ' $n$ bepaalde deel van die land saam te snoer hou groot belofte in.

Die hooftaak van die Departement LTD nl. optimale bodembenutting is geformuleer onder die diepe besef van die groot verwagtinge wat daar van landbouontwikkeling gekoester word. Daar is egter ook rekening gehou met die belangrikheid van die bewaring van die landbouhulpbronne veral teen die agtergrond van die relatiewe skaarsheid daarvan en die feit dat dit reeds grootskaalse agteruitgang toon. Ten spyte van die suksesse wat reeds oor die afgelope paar dekades met bodembewaring gemaak is, is daar nog veel wat in die verband gedoen moet word. Die doeltreffende bewaring van die landbouhulpbronne is vir geen ander doel van groter belang as vir landbouontwikkeling nie. Die diepe besef van die noodsaaklikheid van die bewaring van die landbouhulpbronne behoort ook vir die natuurliefhebber 'n riem onder die hart te wees omdat ook sy behoeftes daardeur bevredig kan word. Met die stelling word daar nie bedoel dat met die vereistes wat landbouontwikkeling stel en steeds gaan stel daar aan al die grille van die algemene of spesifieke bewaringsbewuste voldoen sal kan word nie. Vanuit 'n weidingsoogpunt sou dit egter beteken dat in die dele waar die mees produktiewe en benutbare plantgemeenskappe die sogenaamde "klimaksplantegroei" verteenwoordig, sal daar na dié tipe plantegroei gestreef word, terwyl waar die plantegroei in terme van veeproduksie die grootste benuttingswaarde voor die "klimaksstadium" het, dan sal daar na so 'n tipe plantegroei gemik word. Die voorbehoud sal egter altyd daar wees dat die primêre hulpbron nl. die grond nie daardeur benadeel sal word nie. Deur besproeiing toe te pas sal daar altoos van die oortollige water wat in die grond mag voorkom ontslae geraak moet word. Die benutting van besproeiingsgrond en water kan egter in die moderne opset so gereël en beheer word dat gemineraliseerde uitvloei vanuit besproeiingsgebiede, wat onvermydelik altyd daar sal wees, tot die minimum beperk sal bly wat nodig is om die soutbalans nie te versteur nie. In die moderne 
landbouontwikkeling is dit ook onvermydelik dat daar van chemiese plaagbeheermiddels gebruik gemaak sal word.

Landbouontwikkeling volgens die beginsels van optimale bodembenutting hou ryke beloftes in vir toekomstige voedsel- en veselvoorsiening asook vir die behoud van die skoonheid van die natuur in ons Republiek van Suid-Afrika.

\section{VERWYSINGS}

ACOCKS, J P H 1975. Veldtypes of South Africa. Mem. bot. Surv. S. Afr. 40.

ANON. 1975. Africa Institute Bulletin. XV (4).

CAMPBELL, J P 1973. Excerpts from a talk as Under Secretary of Agriculture at the 28th annual convention of the Wyoming Association of Conservation districts in Thermopolis, Wyo.

COETZEE, J A 1968. Palaeoecology in Africa. 3. Univ. O.F.S.

DEPARTEMENT LANDBOU-EKONOMIE EN BEMARKING. 1976. Kortbegrip van Landboustatistiek.

DEPARTEMENT LANDBOU-EKONOMIE EN BEMARKING. 1976. Rekords.

DEPARTEMENT LANDBOU-TEGNIESE DIENSTE. 1972. Rekords Afdeling. Notas vir gebruik deur Sy Edele die Minister van Landbou vir Senaatsmosie.

DEPARTEMENT LANDBOU-TEGNIESE DIENSTE. 1976. Rekords Afdeling. Landbou-ingenieurswese.

DEPARTEMENT VAN STATISTIEK. 1976. Population projections for the RSA 1970 to 2020 .

DU PLESSIS, S J 1968. Die Landboupotensiaal van die natuurfisiese hulpbronne in Suid-Afrika. Simposium : Landboukommunikasie.

IMMELMAN, D W 1967. Bewaringsboerdery-toestande in die Bo-Oranje opvanggebied. D. Agric. (Inst. Agrar.) - proefskrif. Univ. Pretoria.

MACVICAR, C N, D M SCOTNEY, T E SKINNER, H S NIEHAUS, and S H LOUBSER. 1974. A classification of land (climate, terrain form, soil) primarily for rainfed agriculture. S.A. Journal of Agric. Extension. 3.

ORGANISATION FOR ECONOMIC CO-OPERATION AND DEVELOPMENT (OECD). 1975. Agricultural Policy Report.

TIDMARSH, C E 1968. 'n Beeld van ons natuurlike rykdom. Radiorede.

TOMLINSON, F R 1968. Verslag van die interdepartementele studiekomitee oor die gebruik van landbougrond. Rekords Afdeling, Departement Landbou-tegniese Dienste.

VERBEEK, W A 1975. Food and Agriculture. Associated Scientific and Technical Societies of S.A. Conference on Resources of southern Africa. 